\title{
Development of Video Media Based on Powtoon in Social Sciences
}

\author{
Yanuari Dwi Puspitarini ${ }^{1}$, Muhammad Akhyar ${ }^{2}$, Djono ${ }^{3}$
}

\section{ARTICLE INFO}

Article History:

Received 14.09.2018

Received in revised form

08.01.2019

Accepted

Available online 01.04.2019

\begin{abstract}
The development of science and technology cannot be separated from the world of education, one component that is affected is the media used in the learning process. The purpose of this study was to identify the process of developing Powtoon-based video media, the quality of Powtoon-based video media developed, and the effectiveness of Powtoon-based video media to improve learning outcomes in social studies. Powtoon-based video media were developed using ASSURE develo pment models, namely: 1) Analy ze Learner, 2) State Objectives, 3) Select Methods, Media and Materials, 4) Utilize Media and Materials, 5) Require Learner Participation, and 6) Evaluate and Revise. The quality of Powtoon-based video media based on expert validation (material and media) and product trials obtained results of 4,23 with very good and appropriate categories for use in learning processes. The research design used was an experimental design. the sample used in the effectiveness test was 58 students in two different elementary schools. Students are divided into two, namely 29 students for the experimental class and 29 students for the control class. The results of the Powtoon-based video media effectiveness test on learning outcomes obtained an average value in the control class of 65.52 and the average value in the experimental class was 76.90. Sig value (2tailed) obtained at the Independent Sample-T Test of 0.002 . The result of the sig value. (2-tailed) 0.002 $<0.05$ This indicates that there are signific ant differences in learning outcomes between the control class and the experimental class.
\end{abstract}

(C) IJERE. All rights reserved

Keywords:

Instructional Media, Social Sciences, Powtoon Application.

\section{INTRODUCTION}

Learning is one of the important things in the world of education. This learning process can occur both inside and outside the classroom. According to the National Education System Law No. 20 of 2003, learning is a process of interaction between students and teachers and learning resources in a learning environment. The purpose of learning is to gain knowledge (cognitive), a formation of attitudes (affective), and mastery of certain competencies (psychomotor). The success of learning can be seen from the achievements/learning outcomes achieved by students, changes in attitudes and skills possessed by students after the learning process is complete. Susanto (2015) explains about learning outcomes are changes that occur in students, both discussing cognitive, affective, and psychomotor aspects as a result of learning activities.

The development of science and technology currently greatly affects all aspects of human life and includes education. This educational aspect is very closely related to the learning process in schools that have components in the learning process. Sanjaya (2013) mentions the components of the learning process including: 1) goals, 2) content ( material, 3) method, 4) media, and 5) evaluation. One component that is strongly influenced by technological developments in the media used in the learning process. Learning media that are used appropriately can be the main or supporting tool in the learning process so that learning objectives can be achieved efficiently and effectively.

Learning media can be utilized at all levels of education, ranging from early childhood education, basic education, secondary education, and higher education. This research focuses on the development of learning media at the basic education level. Sumantri and Syaodih (Rini, Suryani \& Fadhilah, 2019) stated that elementary schoolis the level of basic education in Indonesia which has a very important role in efforts to improve the quality of human resources (HR). The use of media in the learning process is expected to improve learning outcomes and improve the quality of human resources.

The role of teachers and facilities in schools is one factor in the use of media in learning. The results of interviews and observations carried out in SD Negeri 2 Arenan and SD Negeri 3 Cipawon, obtained

\footnotetext{
1; tp11010.yanuaridwi@gmail.com,orcid.org/0000-0001-9169-1457

2;orcid.org/0000-0001-9176-1371

3;orcid.org/0000-0003-0938-9369

1,2,3, Sebelas Maret University
} 
Puspitarini,Y.D. Akhyar,M. \& Djono (2019). Development of video media based on powtoon in social sciences. International Journal of Educational Research Review, 4(2), 198-205.

information that 1) learning in the classroom using the lecture method/conventional method, especially on memorized material such as historical material, 2) learning resources used in delivering material are textbooks, student worksheets, and electronic school books (BSE), 3) media used in the social studies learning process using images, maps, etc., 4) students are less interested in memorizing material and are quickly bored with the delivery of material using only textbooks, 5) student learning outcomes are not maximal with minimum completeness criteria (KKM) in social studies subjects are 62, and 6) facilities in schools such as the internet, laptops, LCDs, and projectors have not been used optimally.

\section{Instructional Media}

Through the development of science and technology, technology can be utilized in various aspects of human life. One of them in the aspect of education is utilizing technology as a medium in delivering learning material. AECT (Association of Education and Communication Technology) in Sukiman (2012) states that media are all forms and channels that can be used to convey messages or information.

Musfiqon (2012) defines learning media as a physical and non-physical tool used by teachers in delivering material to students to be more effective and efficient. The use of instructional media is expected to be more quickly accepted by students and attracts students to learn. The definition of learning media is also suggested by Miarso (2009) who states that learning media is everything that can be used to convey messages so that it can stimulate students' feelings, thoughts, willingness, and attention and encourage learning.

Media commonly used in the learning process is in the form of sound media (audio) and text or images (visual). The current technological development allows the media used in the learning process to be video. Media video was chosen because the video does not only display material in the form of sound (audio) or only text or images (visual). According to Asyhar (2012), video media can display elements of images (visual) and sound (audio) simultaneously when communicating messages or information. Video media can be used in small / individual or large scale/group learning.

Learning media can be used to convey any material, starting from textual and contextual material. Submission of material on textual material usually only uses textbooks.

\section{Social Sciences}

According to Trianto (2014), social science is an integration of various branches of social sciences, such as sociology, history, geography, economics, politics, law, and culture. Social studies are formulated on the basis of reality and social phenomena which embody an interdisciplinary approach from the aspects and branches of social sciences (sociology, history, geography, economics, politics, law, and culture. Nur Hadi in Susanto (2015) states that there are four Social studies education goals, namely: knowledge, skills, attitude, and value.

\section{Powtoon Application}

Powtoon is an online web application for making an animated cartoon or video presentations in an easy way. Powtoon is software for creating exposures that have animated features including handwriting animations, cartoon animations, and more vibrant transition effects and easy timing (Ashari, 2018). This Powtoon application is actually almost the same as the PowerPoint application that is commonly used to make presentation media. The way it works is by filling in existing slides with presentation material. Then slides containing material are combined with animations and transitions to make it more interesting. The difference is in the existing animated characters. In Powtoon there are various types of animated characters that can support the material presented. Various animated characters will also make the material delivered more interesting.

The Powtoon application has several advantages including 1) has animated features such as handw riting, cartoons, and various transition effects, 2) reduce teacher verbalism in delivering material, 3) can motivate student to learn, 4) can be used in small or large study groups, and 5) Pow toon is very suitable for learning at the elementary school level, because it looks attractive so students will not be easily bored. While the disadvantages of the Powtoon application include: 1) presentation using the Powtoon is less effective when used at the secondary and high education level. This is because the duration of time is too 
Puspitarini,Y.D. Akhyar,M. \& Djono (2019). Development of video media based on powtoon in social sciences. International Journal of Educational Research Review, 4(2), 198-205.

short so the material delivered is less dense, and 2) the manufacturing process must be connected to the internet and requires a stable internet connection.

The use of media in learning is expected to improve student learning outcomes. Learning media can be used to deliver material to all subjects. One of the subjects that rarely uses technology-based media is social studies, especially in historical material, this is because historical material is easier to tell or convey using the lecture method. The selection of Powtoon applications in the development of learning media is due to the features found in Powtoon applications such as handwriting animation, cartoon animation, and others that will attract the attention of students, especially at the elementary education level.

Based on the description above, the problem to be examined in this study is 1) how is the process of developing Powtoon-based video media?, 2) how is the quality of Powtoon-based video media products?, and 3) Are Pow toon-based video media effectively used in the learning process?

The purpose of this study is 1) to identify the process of developing Powtoon-based video media, 2) to identify the quality of Pow toon-based video media products, and 3) to identify the effectiveness of Pow toonbased video media in the learning process.

\section{RESEARCH METHODS}

The purpose of this study was to determine how the process of developing Powtoon-based video media, the feasibility of developed video media, and the effectiveness of using Powtoon-based video media in the learning process of student learning outcomes. This research will be conducted in several elementary schools in Purbalingga. Sample selection is done by purposive sampling. The sample in the study was based on several criteria, namely: 1) the availability of facilities at each school, 2) the similarity of the curriculum used, namely KTSP, and 3) student learning outcomes in social studies.

The type of research used in this study is research and development. According to Gall, Gall, \& Borg (2003) Educational Research and Development ( $\&$ D) is a process used to develop and validate educational products. The goal of educational research is not to develop products, but rather through basic research or to answer specific questions about practical problems (through applied research).

The development model used in this study is the ASSURE model, namely 1) analysis of student characteristics, 2) set learning objectives, 3) choosing methods, media, and teaching materials, 4) utilizing methods, media and teaching materials, 5) involving students in learning activities, and 6) evaluation.

The first stage in this study was the analysis of student characteristics. Analysis of student characteristics aims to find out how the characteristics of each student in the class. Activities carried out at this stage are preliminary studies by conducting observations in the learning process and interviewing the classroom teacher. The second stage is to determine the learning objectives to be achieved after the learning process. The learning objectives are determined based on the syllabus and lesson plan on the material to be delivered. The learning objectives describe the knowledge, attitudes, and skills students will have after the learning process.

The third stage is choosing media, methods, and teaching materials. The selection of media, methods, and teaching materials that will be used in the learning process is based on the analysis that has been carried out in the first stage. The choice of media, methods, and teaching materials is tailored to the characteristics of students, and facilities available at school. The fourth stage is utilizing media, methods, and teaching materials that have been determined in the fourth stage. Previously expert validation and product testing were needed to assess the product being developed. Expert validation and product tes ting aims to determine whether the product is suitable for use in the learning process.

Data is obtained from expert validation and product testing in the form of quantitative data. The data analysis technique used is descriptive statistical analysis. The quantitative data obtained is then converted into qualitative data with a scale of 5, namely:

Table 1. Conversion of Quantitative Data Into Qualitative Data (Maharani, Suryani, \& Ardianto, 2017) 
Puspitarini,Y.D. Akhyar,M. \& Djono (2019). Development of video media based on powtoon in social sciences. International Journal of Educational Research Review, 4(2), 198-205.

\begin{tabular}{lcl}
\hline Score Interval & Value & Category \\
\hline$X>4,21$ & 5 & Very good \\
\hline $3,40<X \leq 4,21$ & 4 & Good \\
\hline $2,60<X \leq 3,40$ & 3 & Enough \\
\hline $1,79<X \leq 2,60$ & 2 & Less \\
\hline$X \leq 1,79$ & 1 & Very less \\
\hline
\end{tabular}

The fifth stage is involving students in learning activities. After the product is validated, tested and declared feasible to use, then the product is implemented in the learning process in the classroom. The sixth stage is evaluation. This evaluation phase is done to measure the effectiveness of the product on student learning outcomes. The effectiveness test is done using the SPSS application with the Paired-Samples T-Test.

\section{RESULTS AND DISCUSSION}

This research was conducted using the ASSURE model, namely 1) analysis of student characteristics, 2) set learning objectives, 3) choosing methods, media, and teaching materials, 4) utilizing methods, media and teaching materials, 5) involving students in learning activities, and 6) evaluation. The details of the stages of the ASSURE model are as follows:

\section{Analyze Learner}

The first stage is analyzing student characteristics. Analysis of student characteristics is done by observing the learning process and interviewing the classroom teacher. Observation and interview activities (preliminary studies) were conducted at 2 Arenan Public Elementary Schools and Cipawon 3 Public Elementary Schools. The preliminary study conducted not only to find out the characteristics of students, but also the learning process and also to find out what facilities are in school.

The results of the preliminary study conducted obtained information: a) the lecture method is more widely used in the delivery of material, b) student learning resources in the form of textbooks, student worksheets, and drawings, c) utilization of printed books and student worksheets in the learning process is not enough to prepare the material thoroughly to students, d) students get bored easily when the material presented only uses textbooks, student worksheets, and pictures, e) facilities and technology in schools have not been used optimally.

\section{State Objective}

The learning objectives are adjusted to the syllabus and lesson plan of the material to be delivered. According to Purw anti, Gunarhadi, \& Musadad syllabus contains the main components of competencies that will be instilled in students through an activity of learning. Activities must be carried out to instill or shape the competency. In this study the material that will be conveyed is the Preparation of Indonesian Independence and the Basic Formulation of the State (Persiapan Kemerdekaan Indonesia dan Perumusan Dasar Negara). The learning objectives in this material in accordance with the RPP used are students can appreciate the services and roles of the leaders of the struggle in preparing for Indonesian independence.

\section{Select Methods, Media and Materials}

The choice of methods, media, and appropriate teaching materials will make the learning process more optimal in achieving learning goals. The selection of methods, media, and teaching materials is tailored to the characteristics of students and the material to be delivered. The research focus is on developing learning media, so that the media to be developed is also adapted to existing facilities in schools such as the use of LCDs and projectors. The media will be developed in the form of video media with a duration of \pm 20 minutes with the extension of $\mathrm{mp} 4$ so that it can be opened using computers, laptops, or smartphones.

Media development is divided into three stages, namely: 1) pre-production. At this stage the review of the curriculum (determining the material, competency standards, basic competencies, indicators, and learning objectives) that have been carried out is then developed into a media flowchart that contains content from the media to be developed, 2) production. This production stage, the flow chart that has been compiled is then visualized into video form using the Powtoon application, and 3) post-production. After 
the video media was finished production, the video media was then reviewed to avoid any errors in the production process.

\section{Use Media and Materials}

At this stage the product needs to be assessed for its feasibility through validation and testing to the user. Expert validation activities and product trials are conducted to ensure that the products developed are suitable for use in the learning process. Expert validation was carried out by material experts and media experts, while product trials were carried out in two stages, namely limited trials and field trials. Aspects assessed by material experts are aspects of content eligibility, presentation feasibility, and language feasibility. Aspects assessed by media experts are aspects of appearance, audio, convenience, and media effectiveness. The aspects assessed in the user trial are aspects of appearance, material, and benefits. Material expert validation was carried out by 3 experts, while media experts were carried out by 2 experts. Limited group trials were conducted on 8 students, while field trials were conducted on 20 students.

Table 2. Results of material expert validation

\begin{tabular}{lccccc}
\hline \multicolumn{1}{c}{ Aspects } & I & II & III & Average & Category \\
\hline Content & 3.37 & 4.46 & 4.30 & 4.04 & Good \\
\hline Material presentation & 5.00 & 4.50 & 4.50 & 4.67 & Good \\
\hline Language & 3.90 & 4.00 & 3.70 & 3.87 & Good \\
\hline Average of each expert & 4,09 & 4,32 & 4,17 & 4,19 & Good \\
\hline
\end{tabular}

Based on the table above the material assessment of the three experts on the aspect of content eligibility obtained a value of 4.04 with good categories, the feasibility aspect of the presentation was 4.67 with a very good category, and the language feasibility aspect was 3.87 with a good category. The average value of all aspects is 4.19 in the good category.

Table 3. Results of material expert validation

\begin{tabular}{lcccc}
\hline \multicolumn{1}{c}{ Aspects } & I & II & Average & Category \\
\hline Display & 4.00 & 4.00 & 4.00 & Good \\
\hline Audio & 4.17 & 4.00 & 4.09 & Good \\
\hline Ease of use & 4.50 & 4.17 & 4.34 & Very good \\
\hline Media effectiveness. & 4.50 & 4.25 & 4.38 & Very good \\
\hline Average of each expert & 4.29 & 4.10 & 4.20 & Good \\
\hline
\end{tabular}

Based on the table above the media assessment of the two experts on the display aspect scored 4.00 with a good category, the audio aspect was 4.09 with a good category, the ease of use aspect was 4.34 with a very good category, and the feasibility aspect of media effectiveness was $4.38 \mathrm{w}$ ith a very good category. The average value of all aspects is 4.20 in the good category.

Table 4. Product Test Results

\begin{tabular}{ccccccc}
\hline User trials & $\mathbf{N}$ & \multicolumn{3}{c}{ Aspect } & Average & Category \\
\cline { 2 - 5 } & & Display & Material & Benefits & & \\
\hline Limited trials & 8 & 3,38 & 4,29 & 4,39 & 4,35 & Very good \\
\hline Field trials & 20 & 4,18 & 4,16 & 4,24 & 4,19 & Good \\
\hline
\end{tabular}

Based on the table above, the results of a limited trial are obtained with an average product rating of 4,35 with a very good category, while the results of field trials with an average product rating of 4,19 are in the good category.

The results of the validation of material experts, media experts, and product trials from users can be summarized in the table below: 
Puspitarini,Y.D. Akhyar,M. \& Djono (2019). Development of video media based on powtoon in social sciences. International Journal of Educational Research Review, 4(2), 198-205.

Table 5. Product Feasibility Test Results

\begin{tabular}{cccc}
\hline No & Respondent & Assessment & Category \\
\hline 1 & Media Expert & 4,20 & Good \\
\hline 2 & Materi Expert & 4,19 & Good \\
\hline 3 & Limited trials & 4,35 & Very good \\
\hline 4 & Field trials & 4,19 & Good \\
\hline & Overall Average Score & 4,23 & Very good \\
\hline
\end{tabular}

Based on the table above the results obtained from the validation of material experts, media experts, limited trials, and field trials were 4,23 with very good categories. The results of the product feasibility test show that the products developed are feasible to be used in the learning process in social studies on the material preparing for Indonesian Independence and State Basic Formulation (Persiapan Kemerdekaan Indonesia dan Perumusan Dasar Negara).

\section{Request Student Participation}

At this stage the product that has been validated, tested, and declared feasible, is then used in the learning process. This product will be implemented in social studies learning in fifth grade at the State Elementary School 2 Sidareja and the State Elementary School 2 Arenan.

\section{Evaluation and Revision}

The final stage of this research is the evaluation phase. Evaluation is done to determine the effectiveness of the product on social studies learning outcomes. This evaluation phase was carried out in the experimental class and the control class. The learning process in the experimental class uses products that have been developed, while the control class uses conventional media. the State Elementary School 2 Sidareja was used as the experimental class and the State Elementary School 2 Arenan was used as a control class. Before testing the effectiveness of the experimental class and the control class, equality tests are needed to find out whether the initial data in the experimental class and the control class are equivalent. The equality test consists of normality test, homogeneity test, and equality test. A summary of the prerequisite tests can be seen in the table below:

Table 6. Summary of Equality Test

\begin{tabular}{llcc}
\hline \multicolumn{1}{c}{ Test } & Sig. & Result \\
\hline a. & Normality & & \\
& Control class & 0,163 & Normal \\
& Experiment class & 0,118 & Normal \\
b. Homogenity & 0,636 & Homogenous \\
c. & Equivalence & 0,431 & Equivalent \\
\hline
\end{tabular}

The table above shows that the experimental class and the control class have normal, homogeneous, and equivalent initial data.To determine whether the product being developed is effectively used to improve learning outcomes in the experimental class and control class, the effectiveness test through the Independent Sample T-Test is carried out. Before conducting an Independent Sample T-Test, a prerequisite test is needed by conducting a normality test and homogeneity test. The hypotheses used to make test decisions are:

a. Hypostheses

$\mathrm{H}_{0}$ : $\quad$ There was no difference in learning outcomes between the control class and the experimental class

$\mathrm{H}_{1}$ : There are differences in learning outcomes between the control class and the experimental class

b. Testing using a two-sided test with a significance level of $\alpha=0.05$ or $5 \%$.

c. Test Decisions:

(1) $\mathrm{H} 0$ is accepted if the probability value is significant or sig. $>0.05$.

๑) $\mathrm{H} 0$ is rejected if the probability value is significant or sig. $<0.05$. 
Puspitarini,Y.D. Akhyar,M. \& Djono (2019). Development of video media based on powtoon in social sciences. International Journal of Educational Research Review, 4(2),198-205.

The results of the effectiveness test through the Independent Sample T-Test can be seen in the table below:

Table 7. Results of Effectiveness Tests using Independent Sample T-Test

\begin{tabular}{lllll}
\hline \multicolumn{1}{c}{ Types of Test } & Score & & Sig. & Result \\
\hline a. & Normality Test & & & \\
& Control Class & 65,52 & 0,238 & Normal \\
& Experiment Class & 76,90 & 0,286 & Normal \\
b. Homogenity Test & & 0,604 & Homogenous \\
c. Effectiveness Test & & Sig. (2-tailed) 0,002 & H0 is rejected and H1 accepted \\
\hline
\end{tabular}

The table above shows that the data in the experimental class and the control class are normally distributed and homogeneous. Based on the effectiveness test, the average score of the control class using conventional media in the learning process is 65.52 and the average value of the experimental class using video media in the learning process is 76.90 . Then the Independent Sample T-Test test results were obtained sig. (2-tailed) $0.002<0.05$ which can be concluded that $\mathrm{H} 0$ is rejected and $\mathrm{H} 1$ is accepted. Based on the sig value. (2-tailed) obtained $<0.05$, it can be concluded that there are significant differences between the average learning outcomes of the experimental class and the control class. So from that the use of video media in the effective learning process is used to improve student learning outcomes in social studies subjects on the material Preparation for Indonesian Independence and State Basic Formulation (Persiapan Kemerdekaan Indonesia dan Perumusan Dasar Negara). This is consistent with the research conducted by Haryoko (2009) which shows that student learning outcomes in computer network techniques taught by using audio-visual media have a much higher score compared to computer network engineering students who are taught using conventional approaches. In addition, a similar study conducted by Oktavianingrum (2016) conducted on learning to manage meetings at the IPMI Kusuma Bangsa professional education institution, Surakarta stated that the average value of the learning outcomes of the experimental group using video media was 88.00 higher than the control group. 74.93. Based on these studies it can be concluded that the development of Sparkol Videoscribe audio-visual media is considered effective in improving student learning outcomes. Video media is also utilized in the research conducted by Zhang, Zhou, Briggs, \& Nunamaker in his research, video media is used in e-learning classes in four conditions namely e-learning environment with interactive video, with non-interactive video, without video, and traditional class. The results obtained were students in the e-learning class using interactive videos achieving learning performance that was far better than the other two classroom environmen ts. Furthermore, video media used in Engineering Drawing subjects in Industrial Machining Malaysia students in research conducted by Ismail, Irwan, Othman, Amiruddin, \& Ariffin found that multimedia for animated videos used was significant and able to enhance students' imagination and visualization.

\section{CONCLUSIONS AND SUGGESTIONS}

Based on the results and discussion above, Powtoon-based video media was developed on the basis of learning in the classroom which still uses many lecture methods, especially on memorizing material, learning resources and learning media using textbooks, electronic school books (BSE), images and maps and not yet utilized facilities in schools such as the internet, laptops, LCDs and projectors optimally.

Pow toon-based video media are developed through the ASSURE model, namely: 1) Analyze Learner, 2) State Objectives, 3) Select Methods, Media and Materials, 4) Utilize Media and Materials, 5) Require Learner Participation, and 6) Evaluate and Revises.

The average value of material expert validation is $4,20 \mathrm{with}$ good categories and the average score of media expert validation is 4,19 in the good category. The average score of the experimental product evaluation is limited to 4,35 with a very good category and the average score of the average field trial product is 4,19 in the good category. The results of expert validation and product trials obtained an average value of 4,23 with a very good category. Based on the results of expert validation and product testing, it can be concluded that the Powtoon-based video media is suitable to be used in the social studies learning process on the material for Preparation of Indonesian Independence and Basic State Formulation (Persiapan Kemerdekaan Indonesia dan Perumusan Dasar Negara). 
Puspitarini,Y.D. Akhyar,M. \& Djono (2019). Development of video media based on powtoon in social sciences. International Journal of Educational Research Review, 4(2), 198-205.

The effectiveness test results through the Independent Sample T-Test show the sig value. (2-tailed) of $0.002<0.05$. Based on the sig value. (2-tailed) it can be concluded that there is a significant difference between the learning outcomes of the control class and the experimental class.

Based on the results of the research obtained, researchers suggest: 1) Teachers must be more creative to utilize the learning support facilities available in schools so that more innovative learning and existing facilities are also optimally utilized, and 2) Principals are expected to be able to motivate teachers to be able to use the media in learning according to technological developments, needs and characteristics of students.

\section{REFERENCES}

Ashari, A.R. (2018). Tutorial PowToon. Retrieved November, 2, 2018 from https://www.scribd.com/doc/202979996/Tutorial-PowToon

Asyhar, R. (2011). Kreatif Mengembangkan Media Pembelajaran. Jakarta: Gaung Persada Press.

Gall, M. D., Gall, J. P., \& Borg, W. R. (2003). Educational research: An introduction 7th Ed. New York: Pearson Education Inc.

Haryoko, S. (2009). Efektivitas Pemanfaatan Media Audio-Visual Sebagai Alternatif Optimalisasi Model Pembelajaran. Jurnal Edukasi@Elektro, 5 (1), 1-10.

Ismail, M.E., Irwan Mahazir, I., Othman, H., Amiruddin, M.H., \& Ariffin, A. (2017). The Use of Animation Video in Teaching to Enhance the Imagination and Visualization of Student in Engineering Drawing. Mechanical Engineering, Science and Technology International Conference. Retrieved November, 2, 2018 from https://doi.org/10.1088/1757-899X/203/1/012023.

Maharani, Y. S., Suryani, N., \& Ardianto, D. T. (2017). Pengembangan Multimedia Pembelajaran Interaktif pada Mata Pelajaran Pengolahan Citra Digital di Sekolah Menengah Kejuruan Negeri 8 Semarang. Prosiding Seminar Nasional Teknologi Pendidikan.

Miarso, Y. H. (2009). Menyemai Benih Teknologi Pendidikan. Jakarta: Kencana Prenada Media Group.

Musfiqon. (2012). Pengembangan Media dan Sumber Pembelajaran. Jakarta: Prestasi Pustakaraya.

Oktavianingrum, D. (2016). Pengembangan Media Audio Visual Sparkol Videoscribe dalam Pembelajaran Mengelola Pertemuan/ Rapat di Lembaga Pendidikan Profesi (LPP) IPMI Kusuma Bangsa Surakarta Jurusan Administrasi Perkantoran. Program Studi Teknologi Pendidikan. Pascasarjana FKIP. Universitas Sebelas Maret. Tesis.

Purwanti, D., Gunarhadi, \& Musadad, M. A. (2019). The effect of local-based 2013 curriculum implementation on students' environmental awareness. International Journal of Educational Research Review. 4(1), 65-75.

Rini, A. P., Suryani, N., \& Fadhilah, S. S. (2019). Development of the predict observe explain (POE)-based thematic teaching materials. International Journal of Educational Research Review. 4(1), 1-7.

Sanjaya. (2013). Strategi Pembelajaran (Berorientasi Standar Proses Pendidikan). Jakarta: Kencana.

Sekertariat Negara. (2003). Undang-Undang No. 20 Tahun 2003 tentang Sistem Pendidikan Nasional. Lembaran Negara RI 2003, No. 4301. Sekertariat Negara. Jakarta.

Sukiman. (2012). Pengembangan Media Pembelajaran. Yogyakarta: Pedagogia

Susanto. (2015). Teori Belajar dan Pembelajaran di Sekolah Dasar. Jakarta: Kencana.

Trianto. (2014). Model Pembelajaran Terpadu: Konsep, Strategi, dan Implentasinya dalam Kurikulum Tingkat Satuan Pendidikan (KTSP). Jakarta: Bumi Aksara.

Zhang, D., Zhou, L., Briggs, R. O., \& Nunamaker, J. F. (2006). Instructional video in elearning: Assessing the impact of interactive video on learning effectiveness. Information and Management. 43(1), 15-27. 